\title{
LIST OF FIGURES AND PLATES
}

\section{Figures}

1.1 Virginia Woolf, photographed for Vogue by Maurice Beck and Helen Macgregor, May 1924

2.1 John Millais's unfinished Portrait of Thomas Carlyle, 1877, damaged by a suffragette in 1914 (C) Museum of London

2.2 Contemporary cartoon by 'A Patriot', 1911 (C) Museum of London

7.1 Vanessa Bell's cover jacket design for Walter Sickert: $A$ Conversation by Virginia Woolf (C) Estate of Vanessa Bell, courtesy Henrietta Garnett

7.2 Vanessa Bell's painting Mrs Dalloway's Party, 1920 (C) Estate of Vanessa Bell, courtesy Henrietta Garnett. Private collection

9.1 The Back Dining Room (Thomas Carlyle's house) by Helen Allingham, 1881 C NTPL/John Hammond

10.1 Virginia Woolf's sketch of a study and bath from the Reading Notebooks. The Berg Collection of English and American Literature, New York Public Library, Astor, Lenox and Tilden Foundations and the Society of Authors as the Literary Representative of the Estate of Virginia Woolf

10.2 Virginia Woolf's writing lodge in the back garden at Monk's House, Rodmell. Photograph (c) Victoria Rosner

13.1 The Stephen family and their guests. Virginia Woolf is the child in the middle. St Ives, $c$. 1892. From the Monk's House Photograph Albums of Virginia and Leonard Woolf, Gift of Frederick R. Koch, the Harvard Theatre Collection, Houghton Library

13.2 Virginia Woolf takes centre-stage at Lady Ottoline Morrell's party at Garsington Manor, Oxfordshire, 1923. National Portrait Gallery, London

13.3 'Alice in Wonderland' birthday party for Angelica, age 11, 
8 Fitzroy Street, London, January 1930. Virginia Woolf dressed herself as the March Hare (C) Tate, London 2009

13.4 The Woolfs' sitting room at 52 Tavistock Square, London, 1924, decorated by Duncan Grant and Vanessa Bell. Vogue

(C) Condé Nast Publications Ltd

14.1 'Family Group outside the Dining Room window, Talland House c.1894'. From the Leslie Stephen Photograph Album, 37f, Mortimer Rare Book Room, Smith College, Northampton, MA 01063

14.2 Monk's House, Rodmell, Sussex (back view) (C) NTPL/Eric Crichton 258

16.1 Vanessa Bell's dust jacket design for the Complete Catalogue of the Hogarth Press. Courtesy of the E. J. Pratt Library, Victoria University, Toronto, Canada

16.2 Vanessa Bell's dust jacket design for Monday or Tuesday. Courtesy of the E. J. Pratt Library, Victoria University, Toronto, Canada

16.3 Vanessa Bell's dust jacket design for Mr. Bennett and Mrs.

Brown. Courtesy of the E. J. Pratt Library, Victoria University, Toronto, Canada

16.4 Vanessa Bell's dust jacket design for The Legend of Monte della Sibilla. Courtesy of the E. J. Pratt Library, Victoria University, Toronto, Canada

16.5 The Striped Dress, woodcut by Roger Fry. Courtesy of the

E. J. Pratt Library, Victoria University, Toronto, Canada

16.6 The Servant Girl, woodcut by Carrington. Courtesy of the E. J. Pratt Library, Victoria University, Toronto, Canada

17.1 Illustration from 'Women of To-Day and To-Morrow, By a Man - C. E. M. Joad'. With permission of the Society of Authors as literary representative of the estate of Virginia Woolf

20.1 Page 181 of Woolf's second holograph draft of 'The Movies'. Courtesy of the Henry W. and Albert A. Berg Collection of English and American Literature, the New York Public Library, Astor, Lenox and Tilden Foundations. (c) 2009 the Estate of Virginia Woolf. By permission of the Society of Authors, as the literary representative of the Estate of Virginia Woolf

20.2 Still from The Cabinet of Dr. Caligari, directed by Robert Wiene. Courtesy of the Museum of Modern Art Film Stills Archive, New York

20.3 Still from Entr'acte, directed by René Clair. Courtesy of the Museum of Modern Art Film Stills Archive, New York

20.4 Still from Storm over Asia, directed by Pudovkin. Courtesy of the Museum of Modern Art Film Stills Archive, New York

21.1 'Orlando at the Present Time' from Orlando, photographed by Leonard Woolf. Courtesy of the Society of Authors 
21.2 'A General' from Three Guineas, photographer unknown.

Courtesy of the Society of Authors

22.1 Advertisement, New York Review of Books

22.2 Still from Sammy and Rosie Get Laid, directed by Stephen Frears

22.3 Still from Me, I'm Afraid of Virginia Woolf, directed by Stephen Frears

24.1 Ground-plan drawings from the programme for Imre Kiraly's Venice: The Bride of the Sea. A grand historic and romantic spectacle and aquatic pageant exhibiting in London, London: G. Newnes, 1891

24.2 Adaptations of Woolf's novels for the stage (C) Steven Putzel

24.3 To the Lighthouse, Berkeley Repertory Theater. Photograph by Kevin Berne, www.kevinberne.com

24.4 Waves, National Theatre. Photograph by Stephen Cummiskey

24.5 Orlando, American Conservatory Theater. Photograph by David Wilson, American Conservatory Theater

25.1 Anna Pavlova with her pet swan Jack at Ivy House, her home in London. Image courtesy of the Dance Collection, the New York Public Library at Lincoln Center

25.2 Nijinsky as Harlequin and Lopokova as Columbine in Le Carnaval, which they danced together in Europe in 1910. Image courtesy of the Dance Collection, the New York Public Library at Lincoln Center

25.3 Red Stone Dancer, by Henri Gaudier-Brzeska, 1913-14 (bronze cast of 1969), $426 \times 230 \times 224 \mathrm{~mm}$. Image courtesy of Kettle's Yard, University of Cambridge

25.4 Dancer, by Henri Gaudier-Brzeska, 1913 (bronze cast of 1967), $765 \times 220 \times 210 \mathrm{~mm}$. Image courtesy of Kettle's Yard, University of Cambridge

\section{Plates}

\section{Between pages 180 and 181}

1 Sir Leslie Stephen, by George Frederic Watts, 1878 (oil on canvas) (C) National Portrait Gallery, London

2 Women's Socialist and Political Union suffragist badge, 1908-14

3 Self-Portrait at the Easel, by Vanessa Bell, 1912 (C) Estate of Vanessa Bell, courtesy Henrietta Garnett. Private collection, England

4 Virginia Woolf in a Deckchair, by Vanessa Bell, 1912 (C) Estate of Vanessa Bell, courtesy Henrietta Garnett. Private collection

5 Study for a Composition, by Vanessa Bell, 1930 (c) Estate of Vanessa Bell, courtesy Henrietta Garnett. King's College, Cambridge 
6 The Green Necklace, by Vanessa Bell, 1932 (C) Estate of Vanessa Bell, courtesy Henrietta Garnett. Collection Charles Samuel Stevens

7 Gassed by John Singer Sargent, 1919 (C) The Art Archive/Imperial War Museum

8 Anrep mosaics at the National Gallery, London (C) The National Gallery, London. By courtesy of the Anrep Estate

Between pages 436 and 437

9 The Brown Gallery at Knole, Vita Sackville-West's family home,Kent (C) NTPL/Andreas von Einsiedel

10 The seventeenth-century Monk's House in Rodmell, former home of Virginia and Leonard Woolf (c) NTPL/Eric Crichton

11 The sitting room at Monk's House (C) NTPL/Eric Crichton

12 Vanessa Bell's dust jacket designs for To the Lighthouse, Kew Gardens and Mrs Dalloway. Courtesy of the E. J. Pratt Library, Victoria University, Toronto, Canada

13 Vanessa Bell's dust jacket designs for The Captain's Death Bed, Granite छ่ Rainbow, Virginia Woolf छ Lytton Strachey: Letters and A Writer's Diary. Courtesy of the E. J. Pratt Library, Victoria University, Toronto, Canada

14 Vanessa Bell's dust jacket design for Jacob's Room. Courtesy of the E. J. Pratt Library, Victoria University, Toronto, Canada

15 The Gentleman from San Francisco and Other Stories, by I. A. Bunin and Paris, by Hope Mirrlees. Courtesy of the E. J. Pratt Library, Victoria University, Toronto, Canada

16 Vanessa Bell's dust jacket designs for The Common Reader, The Years and Three Guineas. Courtesy of the E. J. Pratt Library, Victoria University, Toronto, Canada 